\title{
Opieka pielęgniarska nad pacjentką w przebiegu choroby Alzheimera z wykorzystaniem ICNP®
}

\author{
Nursing care for a patient in the Alzheimer's disease \\ course with the use of ICNP®
}

KAROLINA KRAJEWSKA ${ }^{1}$

${ }^{1}$ Studenckie Koło Naukowe Nauk o Zdrowiu, Instytut Nauk o Zdrowiu, Państwowej Uczelni Zawodowej we Włocławku

DOI: http://dx.doi.org/10.21784/IwP.2020.016

ISSN: 2451-1846

\section{Streszczenie:}

Wstęp. Choroba Alzheimera (AD - Alzheimer Disease) to nieuleczalna choroba neurodegeneracyjna. Głównym jej objawem jest znaczne pogorszenie się pamięci. Wraz z wiekiem rośnie prawdopodobieństwo zachorowania na nią. Czynnikami ryzyka rozwoju choroby Alzheimera jest przede wszystkim: cukrzyca, płeć żeńska, nadciśnienie tętniczego oraz brak aktywności fizycznej. Szacuje się, że w Polsce choroba Alzheimera dotyka około 200 tysięcy osób. Według danych statystycznych $60 \%$ wszystkich postaci otępienia to AD.

Cel pracy. Celem pracy jest ukazanie czynności, jakie powinna wykonać pielęgniarka opiekując się pacjentką ze stwierdzoną chorobą Alzheimera.

Prezentacja przypadku. Pacjentka, lat 75, przyjęta do oddziału internistycznego, Ma problemy z komunikowaniem się, przełykaniem treści pokarmowej oraz zaburzenia orientacji przestrzennej. Wymaga stałej asysty w wyko- 
nywaniu czynności dnia codziennego. Uskarża się na nietrzymanie moczu oraz stolca.

Wnioski. Dzięki holistycznemu podejściu do pacjentki możliwe jest zapewnienie jej odpowiedniej opieki oraz poprawa jakości życia pacjentki i jej rodziny.

Słowa kluczowe: choroba Alzheimera, proces pielęgnowania, ICNP®.

\section{Summary:}

Introduction. Alzheimer's disease (AD - Alzheimer Disease) is an incurable neurodegenerative disease. The main source of memory discomfort is destruction. With age, irresistibly falling ill with it. Risk factors for the development of Alzheimer's disease are primarily: diabetes, female gender, hypertension and the lack of a control field. It is estimated that in Poland Alzheimer's disease affects about 200,000 people. According to statistics, $60 \%$ of all forms of dementia are AD.

Aim of the study. The aim of the study is to present the activities that should be performed by a nurse caring for a patient with diagnosed Alzheimer's disease.

Case study. A 75-year-old patient admitted to the internal medicine ward, she has communication, content swallowing and spatial orientation disorders. It requires constant assistance in the performance of everyday activities. He complains of urinary and faecal incontinence.

Conclusion. Thanks to the holistic approach to the patient, it is possible to ensure her correctness and the approach of the patient and her family.

Keywords: Alzheimer's disease, nursing process, ICNP®.

\section{Wstęp}

Choroba Alzheimera (Alzheimer Disease) niegdyś była nazywana jako przedstarczy zanik mózgu lub otępienie pierwotne. AD jest zwyrodnieniem mózgu, w którym dochodzi do obumierania komórek mózgu, dotyczy to szczególnie komórek kory czołowej albo hipokampa [1]. 
Alzheimer Disease prowadzi do nieodwracalnych zmian w ludzkim mózgu, które skutkują przede wszystkim pogorszeniem się pamięci oraz wahaniami nastroju. U osoby chorej zostaje zaburzony zostaje także tok myślenia oraz rozwiązywanie różnych sytuacji [2].

Najczęściej występującą postacią otępienia jest choroba Alzheimera. Wraz ze starzeniem się człowieka rośnie ryzyko zachorowania na chorobę otępienną. W wieku 60 lat prawdopodobieństwo wynosi około 1\%, natomiast w wieku 80 lat zwiększa się i osiąga wartość $20 \%$, a w wieku 90 lat ryzyko wzrasta od 30 do 50\% [3].

Badania przeprowadzane w Stanach Zjednoczonych w 2011 roku ukazują, że w ciągu dziesięciu ostatnich lat od ich opublikowania liczba zgonów wynikających z choroby Alzheimera zwiększyła się do około 87\%. W 2008 roku AD było trzecią przyczyną śmierci Amerykanów zaraz po chorobach układu krążenia oraz chorobach nowotworowych [2].

Prowadzone dane statystyczne w Polsce potwierdzają, że liczba odnotowanych przypadków AD wynosi około dwieście tysięcy. Okazuje się, że przekraczając próg 65 lat ryzyko zachorowania na AD w naszym kraju wynosi $0,2 \%$, po 75 rż. zwiększa się do 0,7\%, w grupie osób 85 lat i więcej prawdopodobieństwo wynosi około 3\%, a w wieku 90 r.ż. zwiększa się do $16 \%$ [4].

Okazuje się, że Polsce średnia wieku rozpoznania choroby Alzheimera wynosi 58 lat oraz częściej dotyczy mężczyzn. W Polsce zachorowalność na różne typy otępień sięga 500 tysięcy, z czego około $50 \%$ przypada na chorobę Alzheimera [5].

Do przyczyn, które wpływają na rozwój choroby Alzheimera należą zarówno czynniki zewnętrzne jak i wewnętrzne. Literatura podaje, że jedynie $15 \%$ przypadków AD jest dziedziczone, a $85 \%$ wynika z innych przyczyn.

Wśród środowiskowych oraz genetycznych czynników należy wyróżnić przede wszystkim:

- długość życia oraz wystąpienie AD u innych członków rodziny, 
- brak wykształcenia,

- przebyte obrażenie głowy,

- zatajona infekcja ośrodkowego układu nerwowego,

- powstanie nieprawidłowości w prekursorze białka amyloidowego - APP (Amyloid Precursor Protein) [2],

- choroby cywilizacyjne takie jak cukrzyca i nadciśnienie tętnicze,

- podwyższone wartości cholesterolu oraz nieprawidłowa praca mięśnia sercowego [6].

\section{Cel}

Celem pracy jest analiza zadań pielęgniarki $\mathrm{w}$ opiece nad pacjentką z potwierdzoną chorobą Alzheimera przy zastosowaniu odpowiednich interwencji i diagnoz pielęgniarskich. W poniższym zaproponowanym planie opieki oparto się na standardowym modelu procesu pielęgnowania, który został uzupełniony o Międzynarodową Klasyfikację Praktyki Pielęgniarskiej ICNPß.

\section{Materiał i metody}

W pracy została zastosowana metoda indywidualnego przypadku, przy pomocy takich technik jak: obserwacja chorego, wywiad bezpośredni, analiza dokumentacji medycznej (historii choroby, wyników badań, karty gorączkowej, karty indywidualnej opieki pielęgniarskiej), pomiar podstawowych parametrów życiowych (tętno, ciśnienie tętnicze krwi, częstość oddechów, temperatura ciała). Pacjentka wyraziła zgodę na badanie, które zostało przeprowadzone w pierwszym półroczu 2020r. Opierając się na zebranych informacjach poniżej zaprezentowano określone diagnozy pielęgniarskie oraz przygotowano indywidualny plan opieki pielęgniarskiej z zastosowaniem klasyfikacji ICNP®. 


\section{Prezentacja przypadku}

Pacjentka, lat 75, urodzona w Aleksandrowie Kujawskim. Pacjentka mieszka sama, w ciągu dnia może liczyć na pomoc syna i córki, którzy prowadzą oddzielne gospodarstwa domowe. Wcześniej dwukrotnie przyjęta do szpitala z powodu pogarszającego się stanu zdrowia.

Pacjentka z rozpoznaną chorobą Alzheimera około pięć lat temu, w rodzinie w przeszłości zostały zdiagnozowane dwa przypadki choroby Alzheimera. Obecnie w drugim stadium choroby. Obecnie w pierwszej dobie pobytu, przyjęta do oddziału internistycznego, z powodu pogorszenie stanu zdrowia: utrudniony kontakt z bliskimi, problem z przełykaniem pokarmu. Ponadto pacjentka leczy się także nieskutecznie na nadciśnienie tętnicze od 20 lat, z powodu deficytu wiedzy jest ono źle kontrolowane. Chora ma także deficyty w zakresie wykonywania czynności samopielęgnacyjnych. Stan pacjentki z dnia na dzień znacząco się pogorszył, zwłaszcza w sferze komunikacji werbalnej. Utrzymują się także zaburzenia pamięci świeżej oraz trudności w przemieszczaniu się. Pacjentka uskarża się także na nietrzymanie moczu oraz stolca. W ostatnim czasie rodzina miksowała pacjentce posiłki z powodu problemów z przełykaniem treści pokarmowej, a następnie krztuszeniem się.

Na chwilę obecną ryzyko upadku według skali Tinetti wynosi 19 puntów. Ciśnienie tętnicze wynosi 140/90 mmHg. Temperatura ciała w normie $-36,6^{\circ} \mathrm{C}$. Chora wykazuje deficyty wiedzy na temat choroby i samoopieki.

W Tabeli 1. zaprezentowano szczegółowe informacje o chorej oraz wyniki badania podmiotowego. 
Tab. 1. Arkusz indywidualnego opisu przypadku opracowanie na podstawie Lesińska-Sawicka M. (2009).

\begin{tabular}{|l|l|}
\hline \multicolumn{2}{|l|}{ Dane socjodemograficzne } \\
\hline Rok urodzenia: 04.05.1945r. & Płeć: Kobieta \\
\hline Stan cywilny: Wdowa & Wykonywany zawód: Nauczycielka \\
\hline
\end{tabular}

\begin{tabular}{|l|}
\hline \multicolumn{1}{|c|}{ STAN OGÓLNY (podczas zbierania wywiadu) } \\
\hline Temperatura: $36,6^{\circ} \mathrm{C}$ \\
\hline Tętno: (liczba / napięcie / rytm) 80/min, dobrze napięte, miarowe \\
\hline Oddechy: $17 / \mathrm{min}$. \\
\hline Ciśnienie tętnicze: $140 / 90 \mathrm{mmHg}$ \\
\hline Masa ciała: $58 \mathrm{~kg}$ \\
\hline Wzrost: $160 \mathrm{~cm}$ \\
\hline BMI: 22,66 \\
\hline
\end{tabular}

\begin{tabular}{|l|}
\hline \multicolumn{1}{|c|}{ WYWIAD RODZINNY } \\
\hline Członkowie rodziny: córka (45 lat), syn (50 lat) \\
Ważne wydarzenia w rodzinie - ostatnie lata: śmierć małżonka \\
Choroby występujące w rodzinie: nadciśnienie tętnicze, nowotwory jelit, \\
choroba Alzheimera \\
Hobby/zainteresowania: szydełkowanie \\
Formy spędzania czasu wolnego: oglądanie telewizji, wyjście do sq̨siadki \\
Nałogi w rodzinie: - \\
Błędy żywieniowe - jakościowe i ilościowe: nieregularne spożywanie po- \\
siłków \\
Ograniczenia/przeciażenia psychicznego/fizyczne: zawroty głowy pod- \\
czas lekkiego wysiłku \\
Ograniczone kontakty/brak wsparcia społecznego:
\end{tabular}


Tab. 2. Badanie fizykalne - opracowanie na podstawie Lesińska-Sawicka M. (2009).

\begin{tabular}{|c|c|l|l|l|l|c|}
\hline \multicolumn{2}{|c|}{ SKÓRA } \\
\hline $\begin{array}{c}\text { napię- } \\
\text { cie }\end{array}$ & $\begin{array}{c}\text { tempe- } \\
\text { ratura }\end{array}$ & zabarwienie & $\begin{array}{c}\text { wilgot- } \\
\text { ność }\end{array}$ & $\begin{array}{c}\text { stan } \\
\text { higie- } \\
\text { niczny }\end{array}$ & $\begin{array}{c}\text { inne } \\
\text { objawy }\end{array}$ & $\begin{array}{c}\text { stan } \\
\text { rany po- } \\
\text { opera- } \\
\text { cyjnej }\end{array}$ \\
\hline $\begin{array}{c}\text { prawi- } \\
\text { dłowe }\end{array}$ & $\begin{array}{c}36,6 \\
{ }^{\circ} \mathrm{C}\end{array}$ & prawidłowe & $\begin{array}{c}\text { prawi- } \\
\text { dłowa }\end{array}$ & średni & brak & $\begin{array}{c}\text { nie doty- } \\
\text { czy }\end{array}$ \\
\hline
\end{tabular}

\begin{tabular}{|c|c|c|c|c|}
\hline \multicolumn{5}{|c|}{ UKŁAD ODDECHOWY } \\
\hline $\begin{array}{c}\text { liczba } \\
\text { oddechów }\end{array}$ & typ oddechu & kaszel & inne objawy & $\begin{array}{c}\text { wyroby } \\
\text { medyczne }\end{array}$ \\
\hline $17 / \mathrm{min}$ & prawidłowy & brak & brak & nie dotyczy \\
\hline
\end{tabular}

\begin{tabular}{|c|c|c|c|c|c|c|}
\hline \multicolumn{7}{|c|}{ UKŁAD KRĄŻENIA } \\
\hline ciśnienie & tętno & sinica & obrzęki & $\begin{array}{c}\text { dusz- } \\
\text { ność }\end{array}$ & $\begin{array}{c}\text { inne } \\
\text { objawy }\end{array}$ & $\begin{array}{c}\text { satura- } \\
\text { cja }\end{array}$ \\
\hline $\begin{array}{c}140 / 90 \\
\text { mmHg }\end{array}$ & $80 / \mathrm{min}$ & brak & brak & brak & brak & $\begin{array}{c}97 \% \\
\text { Sp02 }\end{array}$ \\
\hline \multicolumn{7}{|c|}{ UKŁAD POKARMOWY } \\
\hline uzębienie & łaknienie & stolec & dieta & $\begin{array}{c}\text { inne } \\
\text { objawy }\end{array}$ & $\begin{array}{c}\text { sposób } \\
\text { odżywia- } \\
\text { nia }\end{array}$ \\
\hline proteza & $\begin{array}{c}\text { prawi- } \\
\text { dłowe }\end{array}$ & $\begin{array}{c}\text { prawi- } \\
\text { dłowe }\end{array}$ & $\begin{array}{c}\text { papko- } \\
\text { wata }\end{array}$ & brak & doustny \\
\hline
\end{tabular}

\begin{tabular}{|c|c|c|c|}
\hline \multicolumn{4}{|c|}{ UKŁAD MOCZOWY } \\
\hline objętość & jakość & inne objawy & $\begin{array}{c}\text { wyroby } \\
\text { medyczne }\end{array}$ \\
\hline $1,5 \mathrm{l}$ & $\begin{array}{c}\text { barwa słom- } \\
\text { kowa }\end{array}$ & $\begin{array}{c}\text { nietrzymanie } \\
\text { moczu }\end{array}$ & pieluchomajtki \\
\hline
\end{tabular}




\begin{tabular}{|c|c|c|}
\hline \multicolumn{3}{|c|}{ UKŁAD PŁCIOWY } \\
\hline cykl płciowy & inne objawy & inne cechy (u dzieci) \\
\hline adekwatny do wieku & brak & nie dotyczy \\
\hline
\end{tabular}

\begin{tabular}{|c|c|c|c|}
\hline \multicolumn{4}{|c|}{ UKŁAD NERWOWY } \\
\hline $\begin{array}{c}\text { świadomość wg } \\
\text { skali Glasgow }\end{array}$ & $\begin{array}{c}\text { niedowłady / } \\
\text { drżenia }\end{array}$ & mowa & inne objawy \\
\hline 15 & brak & $\begin{array}{c}\text { utrudniony } \\
\text { kontakt }\end{array}$ & $\begin{array}{c}\text { zaburzenia } \\
\text { funkcji poznaw- } \\
\text { czych }\end{array}$ \\
\hline
\end{tabular}

Stan psychiczny i społeczny podopiecznego

\begin{tabular}{|c|c|c|c|}
\hline sen & nastrój & inne objawy & $\begin{array}{c}\text { ocena wg skali } \\
\text { GDS (seniorzy) }\end{array}$ \\
\hline prawidłowy & dobry & brak & $\begin{array}{c}15-\text { łagodna } \\
\text { depresja }\end{array}$ \\
\hline
\end{tabular}

\section{Diagnozy i interwencje pielegniarskie}

Po przeprowadzonych badaniach podmiotowych i przedmiotowych u pacjentki wyróżnia się następujące problemy: problemy z komunikowaniem się spowodowane postępującym przebiegiem choroby, nietrzymanie moczu oraz stolca wynikające z postępu AD, ryzyko zakrztuszenia wynikające z zaburzeń połykania w przebiegu choroby, utrudnione poruszanie się wynikające z postępu choroby Alzheimera, zaburzenie orientacji allopsychicznej w przebiegu choroby Alzheimera, deficyt samoopieki wynikający z choroby Alzheimera.

Poniżej przedstawiono plan opieki pielęgniarskiej nad pacjentką w odniesieniu do zdiagnozowanych problemów pielęgnacyjnych z wykorzystaniem Międzynarodowej Klasyfikacji Praktyki Pielęgniarskiej ICNP® (Tabela 3.) 
Opieka została zaplanowana i zrealizowana w oparciu o modele D. Orem częściowo-kompensacyjny oraz na całościowym spostrzeganiu człowieka zgodnie z przekonaniami C. Roy.

Poniżej, w Tabeli 3., zaprezentowano najważniejsze problemy pielęgnacyjne opisywanej chorej w sposób tradycyjny oraz z wykorzystaniem ICNP®.

Tab. 3. Proces pielęgnowania pacjentki z anoreksją z wykorzystaniem ICNP®.

\begin{tabular}{|l|l|}
\hline Problem pielęgnacyjny I & Diagnoza negatywna (+kod ICNP®) \\
\hline $\begin{array}{l}\text { Problemy z komunikowaniem } \\
\text { się spowodowane postępują- } \\
\text { cym przebiegiem choroby. }\end{array}$ & $\begin{array}{l}\text { zaburzona komunikacja werbalna } \\
{[10025104]}\end{array}$ \\
\hline $\begin{array}{l}\text { Cel planowanych działań pielę- } \\
\text { gniarskich: }\end{array}$ & Ułatwienie komunikowania się. \\
\hline $\begin{array}{l}\text { Planowane interwencje pielę- } \\
\text { gniarskie: }\end{array}$ & Interwencje pielęgniarskie ICNP®: \\
\hline $\begin{array}{l}\text { ocena możliwości komuniko- } \\
\text { wania się, }\end{array}$ & $\begin{array}{l}\text { ocenianie zdolności komunikowa- } \\
\text { nie werbalnego [10030515] }\end{array}$ \\
$\begin{array}{l}\text { zastosowanie odpowied- } \\
\text { niego sposobu porozumie- } \\
\text { wanie się z chorą (komuni- } \\
\text { kowanie się werbalne i poza- } \\
\text { werbalne) } \\
\text { okazanie pacjentce wyrozu- } \\
\text { miałości i cierpliwości, } \\
\text { docenianie wysiłków pa- } \\
\text { cjentki i zmniejszanie barier } \\
\text { w komunikacji } \\
\text { zapewnienie spokoju pa- } \\
\text { cjentce, }\end{array}$ & $\begin{array}{l}\text { nauczanie pacjenta [10033126] } \\
\text { dowiska [10042507] }\end{array}$ \\
\hline
\end{tabular}




\begin{tabular}{|c|c|}
\hline $\begin{array}{l}\text { edukacja rodziny w zakresie } \\
\text { komunikowania się z pa- } \\
\text { cjentką, }\end{array}$ & \\
\hline $\begin{array}{l}\text { Ocena realizowanych działań } \\
\text { pielęgniarskich: Komunikacja } \\
\text { nadal utrudniona. Działania } \\
\text { pielęgniarskie należy konty- } \\
\text { nuować. }\end{array}$ & $\begin{array}{l}\text { Diagnoza pozytywna/negatywna } \\
\text { ICNPß: } \\
\text { zaburzona komunikacja werbalna } \\
{[10025104]}\end{array}$ \\
\hline \multicolumn{2}{|c|}{ Uzasadnienie planowanej interwencji pielęgniarskiej: } \\
\hline \multicolumn{2}{|c|}{$\begin{array}{l}\text { Dzięki ocenie możliwości komunikowania się pacjentki rozpoznamy na ja- } \\
\text { kim poziomie jest obecne porozumiewanie się jej z otoczeniem. Zastoso- } \\
\text { wanie odpowiedniego sposobu porozumiewania się ułatwi nawiązać do- } \\
\text { brą relację i zmniejszy zdenerwowanie pacjentki. Cierpliwość, wyrozu- } \\
\text { miałość, docenienie chorej poprawi jej pewność podczas prób komunika- } \\
\text { cji [7]. }\end{array}$} \\
\hline Problem pielęgnacyjny II & Diagnoza negatywna (+kod ICNPß) \\
\hline $\begin{array}{l}\text { Nietrzymanie moczu oraz } \\
\text { stolca wynikające z postępu } \\
\text { AD. }\end{array}$ & $\begin{array}{l}\text { nietrzymanie moczu [10025686] + } \\
\text { nietrzymanie stolca [10027718] }\end{array}$ \\
\hline $\begin{array}{l}\text { Cel planowanych działań pielę- } \\
\text { gniarskich: }\end{array}$ & Poprawa funkcjonowania zwieraczy. \\
\hline $\begin{array}{l}\text { Planowane interwencje pielę- } \\
\text { gniarskie: }\end{array}$ & Interwencje pielęgniarskie ICNP®: \\
\hline $\begin{array}{l}\text { - zachowanie prawidłowej hi- } \\
\text { gieny krocza, } \\
\text { - ocena stanu skóry pod kątem } \\
\text { działania drażniącego moczu } \\
\text { i stolca } \\
\text { - obserwowanie w jakich sytua- } \\
\text { cjach dochodzi do nietrzyma- } \\
\text { nie moczu i stolca, } \\
\text { - częsta zmiana pieluchomajtek } \\
\text { oraz zapewnienie czystej bie- } \\
\text { lizny, }\end{array}$ & $\begin{aligned}- & \text { zarządzanie nietrzymaniem moczu } \\
& {[10031879], } \\
- & \text { zarządzanie nietrzymaniem stolca } \\
& {[10046301] } \\
- & \text { ocenianie trzymania moczu } \\
& {[10030781] } \\
- & \text { ocenianie trzymanie stolca } \\
& {[10030558] } \\
- & \text { pielęgnacja skóry }[10032757] \\
- & \text { promowanie higieny }[10032477]\end{aligned}$ \\
\hline
\end{tabular}




\begin{tabular}{|c|c|}
\hline $\begin{array}{l}\text { - } \text { zalecenie ćwiczenia funkcji } \\
\text { zwieraczy, } \\
\text { - wsparcie pacjentki i jej ro- } \\
\text { dziny } \\
\text { - pomoc w wykonywaniu czyn- } \\
\text { ności higienicznych }\end{array}$ & $\begin{aligned}- & \text { kontrola symptomów [10025812] } \\
- & \text { asystowanie w higienie } \\
& {[10030821] } \\
- & \text { wspieranie rodziny [10032844] }\end{aligned}$ \\
\hline $\begin{array}{l}\text { Ocena realizowanych działań } \\
\text { pielęgniarskich: Nietrzymanie } \\
\text { moczu i stolca utrzymują się. } \\
\text { Działania pielęgniarskie należy } \\
\text { kontynuować. }\end{array}$ & $\begin{array}{l}\text { Diagnoza pozytywna/negatywna } \\
\text { ICNP®: } \\
\text { nietrzymanie moczu [10025686] + } \\
\text { nietrzymanie stolca [10027718] }\end{array}$ \\
\hline \multicolumn{2}{|c|}{ Uzasadnienie planowanej interwencji pielęgniarskiej: } \\
\hline \multicolumn{2}{|c|}{$\begin{array}{l}\text { Zachowanie prawidłowej higieny, pomoc w wykonywaniu czynności hi- } \\
\text { gienicznych, ocena stanu skóry, częsta zmiana pieluchomajtek oraz za- } \\
\text { stosowanie czystej bielizny pozwoli na zapewni lepsze samopoczucie fi- } \\
\text { zyczne, psychiczne oraz zmniejszy odczuwanie dyskomfortu. Obserwacja } \\
\text { pacjentki jest konieczne, by można było określić przyczynę nietrzymania } \\
\text { moczu oraz stolca [7]. }\end{array}$} \\
\hline Problem pielęgnacyjny III & Diagnoza negatywna (+kod ICNPß) \\
\hline $\begin{array}{l}\text { Ryzyko zakrztuszenia wynika- } \\
\text { jące z zaburzeń połykania w } \\
\text { przebiegu choroby. }\end{array}$ & zaburzone połykanie [10001033] \\
\hline $\begin{array}{l}\text { Cel planowanych działań pielę- } \\
\text { gniarskich: }\end{array}$ & Zmniejszenie ryzyka zakrztuszenia się. \\
\hline $\begin{array}{l}\text { Planowane interwencje pielę- } \\
\text { gniarskie: }\end{array}$ & Interwencje pielęgniarskie ICNPß: \\
\hline $\begin{array}{l}\text { - ocena samodzielności pa- } \\
\text { cjentki w zakresie spożywa- } \\
\text { nia posiłków } \\
\text { - pomoc w karmieniu pa- } \\
\text { cjentki, }\end{array}$ & $\begin{aligned}- & \text { ocenianie stopnia samodzielności } \\
& {[10002723] } \\
- & \text { zarządzanie bezpieczeństwem śro- } \\
& \text { dowiska [10042507] } \\
- & \text { ocenianie zachowań związanych z } \\
& \text { jedzeniem lub piciem [10002747] }\end{aligned}$ \\
\hline
\end{tabular}




\begin{tabular}{|c|c|}
\hline $\begin{array}{l}\text { - zapewnienie pacjentce odpo- } \\
\text { wieniej pozycji do jedzenia } \\
\text { (siedzącej), } \\
\text { - dostosowanie konsystencji } \\
\text { pokarmu i czasu karmienia } \\
\text { do możliwości przełykania } \\
\text { pacjentki (zmiksowane po- } \\
\text { siłki), } \\
\text { - edukacja rodziny dot. kar- } \\
\text { mienia } \\
\text { - zapewnienie odpowiedniej } \\
\text { temperatury posiłków, } \\
\text { - miła atmosfera podczas po- } \\
\text { siłku }\end{array}$ & $\begin{aligned} \text { - } & \text { nauczanie o przyjmowaniu płynów } \\
& {[10032939] } \\
- & \text { nauczenie o wzorcu przyjmowania } \\
& \text { pokarmu [10032918] } \\
\text { - } & \text { monitorowanie przyjmowania po- } \\
& \text { karmów [10036614] } \\
- & \text { współdziałanie z rodziną } \\
& {[10035887] }\end{aligned}$ \\
\hline $\begin{array}{l}\text { Ocena realizowanych działań } \\
\text { pielęgniarskich: Ryzyko za- } \\
\text { krztuszenia się zmniejszyło się. } \\
\text { Działania pielęgniarskie należy } \\
\text { kontynuować. }\end{array}$ & $\begin{array}{l}\text { Diagnoza pozytywna/negatywna } \\
\text { ICNP®: } \\
\text { zaburzone połykanie [10001033] }\end{array}$ \\
\hline \multicolumn{2}{|c|}{ Uzasadnienie planowanej interwencji pielęgniarskiej: } \\
\hline \multicolumn{2}{|c|}{$\begin{array}{l}\text { Ocena samodzielności pacjentki podczas przyjmowania pokarmów jest } \\
\text { istotna by można było zapewnić chorej odpowiednią pomoc do potrzeb, } \\
\text { jednocześnie nie wyręczając jej, a jedynie wspierając. Rodzaj i konsysten- } \\
\text { cja pokarmu powinna być dostosowana do zaleceń dietetycznych i prefe- } \\
\text { rencji żywieniowych chorej [7]. }\end{array}$} \\
\hline
\end{tabular}

\begin{tabular}{|l|l|}
\hline Problem pielęgnacyjny IV & Diagnoza negatywna (+kod ICNP®) \\
\hline $\begin{array}{l}\text { Utrudnione poruszanie się wy- } \\
\text { nikające z postępu choroby Al- } \\
\text { zheimera. }\end{array}$ & $\begin{array}{l}\text { zaburzona zdolność przemieszczania } \\
{[10001005]}\end{array}$ \\
\hline $\begin{array}{l}\text { Cel planowanych działań pielę- } \\
\text { gniarskich: }\end{array}$ & Zmniejszenie trudności poruszania się. \\
\hline
\end{tabular}




\begin{tabular}{|c|c|}
\hline $\begin{array}{l}\text { Planowane interwencje pielę- } \\
\text { gniarskie: }\end{array}$ & Interwencje pielęgniarskie ICNP®: \\
\hline $\begin{array}{l}\text { - zachęcenie pacjentki do wy- } \\
\text { konywania ćwiczeń, } \\
\text { - ocena ryzyka upadków, } \\
\text { - zapewnienie bezpiecznego } \\
\text { otoczenia pacjentce, } \\
\text { - zachęcenie do korzystania ze } \\
\text { sprzętów pomocniczych, } \\
\text { - włączenie rodziny w pomoc } \\
\text { przy przemieszczaniu się pa- } \\
\text { cjentki, } \\
\text { - zachęcenie do kontaktu z fi- } \\
\text { zjoterapeutą }\end{array}$ & $\begin{aligned}- & \text { ocenianie możliwości [10026040] } \\
- & \text { ocenianie stopnia samodzielności } \\
& {[10002723] } \\
- & \text { demonstrowanie metod prewencji } \\
& \text { upadku [10040248] } \\
- & \text { współdziałanie z rodziną } \\
& {[10035887] } \\
- & \text { zarządzanie bezpieczeństwem śro- } \\
& \text { dowiska [10042507] } \\
- & \text { współdziałanie z zespołem wielo- } \\
& \text { specjalistycznym interdyscyplinar- } \\
& \text { nym [10039416] } \\
- & \text { zastosowanie urządzenia zabezpie- } \\
& \text { czającego [10002472] }\end{aligned}$ \\
\hline $\begin{array}{l}\text { Ocena realizowanych działań } \\
\text { pielęgniarskich: Poruszanie się } \\
\text { pacjentki polepszyło się. Dzia- } \\
\text { łania pielęgniarskie należy kon- } \\
\text { tynuować. }\end{array}$ & $\begin{array}{l}\text { Diagnoza pozytywna/negatywna } \\
\text { ICNP®: } \\
\text { zaburzona zdolność przemieszczania } \\
\text { [10001005] }\end{array}$ \\
\hline \multicolumn{2}{|c|}{ Uzasadnienie planowanej interwencji pielęgniarskiej: } \\
\hline \multicolumn{2}{|c|}{$\begin{array}{l}\text { Wykonywanie ćwiczeń pozwoli pacjentce na polepszanie swojej spraw- } \\
\text { ności fizycznej, a co za tym idzie do lepszego wykonywania czynności sa- } \\
\text { moobsługowych. Zaburzenia psychoruchowe pacjentki wymagają sta- } \\
\text { łego nadzoru dlatego tak ważne jest włączenie rodziny w proces prze- } \\
\text { mieszczania się chorej. Korzystanie ze sprzętu pomocniczego usprawni } \\
\text { funkcjonowanie pacjentki }[4,7,8] \text {. }\end{array}$} \\
\hline Problem pielęgnacyjny $\mathrm{V}$ & Diagnoza negatywna (+kod ICNP $囚)$ \\
\hline $\begin{array}{l}\text { Zaburzenie orientacji allopsy- } \\
\text { chicznej w przebiegu choroby } \\
\text { Alzheimera. }\end{array}$ & dezorientacja [10001235] \\
\hline
\end{tabular}




\begin{tabular}{|c|c|}
\hline $\begin{array}{l}\text { Cel planowanych działań pielę- } \\
\text { gniarskich: }\end{array}$ & $\begin{array}{l}\text { Zmniejszenie zaburzeń orientacji al- } \\
\text { lopsychicznej. }\end{array}$ \\
\hline $\begin{array}{l}\text { Planowane interwencje pielę- } \\
\text { gniarskie: }\end{array}$ & Interwencje pielęgniarskie ICNP®: \\
\hline $\begin{array}{l}\text { - ocena stanu psychicznego } \\
\text { pacjentki, } \\
\text { - ocena funkcji poznawczych } \\
\text { wg skal (MMSE, GDS) } \\
\text { - podaż leków (poprawiają- } \\
\text { cych orientację pacjentki) na } \\
\text { zlecenie lekarza, } \\
\text { - motywacja rodziny do } \\
\text { wsparcia pacjentki, } \\
\text { - zapewnienie kontaktu z ro- } \\
\text { dziną, } \\
\text { - przekazywanie i powtarza- } \\
\text { nie z pacjentką informacji } \\
\text { dot. miejsca pobytu, daty i } \\
\text { czasu } \\
\text { - okazanie empatii pacjentce, } \\
\text { - przestrzeganie stałego planu } \\
\text { dnia } \\
\text { - unikanie zmian w otoczeniu } \\
\text { pacjentki }\end{array}$ & $\begin{aligned}- & \text { administrowanie lekiem } \\
& {[10025444] } \\
- & \text { motywowanie [10012242] } \\
- & \text { zapewnienie wsparcia emocjonal- } \\
& \text { nego [10027051] } \\
- & \text { obserwacja zmienionej percepcji } \\
& {[10013517] } \\
- & \text { zarządzanie bezpieczeństwem śro- } \\
& \text { dowiska [10042507] }\end{aligned}$ \\
\hline $\begin{array}{l}\text { Ocena realizowanych działań } \\
\text { pielęgniarskich: Zaburzenia } \\
\text { orientacji allopsychicznej } \\
\text { utrzymują się okresowo. Dzia- } \\
\text { łania pielęgniarskie należy kon- } \\
\text { tynuować. }\end{array}$ & $\begin{array}{l}\text { Diagnoza pozytywna/negatywna } \\
\text { ICNPß: dezorientacja [10001235] }\end{array}$ \\
\hline
\end{tabular}




\begin{tabular}{|c|c|}
\hline \multicolumn{2}{|c|}{ Uzasadnienie planowanej interwencji pielęgniarskiej: } \\
\hline \multicolumn{2}{|c|}{$\begin{array}{l}\text { Nawiązywanie i powtarzanie niektórych zdarzeń/czynności pozwala na } \\
\text { poprawę pamięci. Poprzez motywowanie wzbudzamy odczucie wspar- } \\
\text { cia. Kontakt z rodziną pozwoli na odczuwanie bezpieczeństwa przez pa- } \\
\text { cjentkę. Stały plan dnia oraz unikanie zmian w otoczeniu chorej spowo- } \\
\text { duje poprawę funkcjonowania psychofizycznego, zmniejszy lęk oraz } \\
\text { zdezorientowanie [7]. }\end{array}$} \\
\hline Problem pielęgnacyjny VI & Diagnoza negatywna (+kod ICNPß) \\
\hline $\begin{array}{l}\text { Deficyt samoopieki wynikający } \\
\text { z choroby Alzheimera. }\end{array}$ & deficyt samoopieki [10023410] \\
\hline $\begin{array}{l}\text { Cel planowanych działań pielę- } \\
\text { gniarskich: }\end{array}$ & $\begin{array}{l}\text { Zmniejszenie deficytu w zaspokojeniu } \\
\text { potrzeb pacjentki. }\end{array}$ \\
\hline $\begin{array}{l}\text { Planowane interwencje pielę- } \\
\text { gniarskie: }\end{array}$ & Interwencje pielęgniarskie ICNP®: \\
\hline $\begin{array}{l}\text { - ocena samoopieki wg skal } \\
\text { (ADL, IADL) } \\
\text { - ocena potrzeb pacjentki, } \\
\text { - ocena w zakresie deficytu sa- } \\
\text { moopieki pacjentki oraz ro- } \\
\text { dziny, } \\
\text { - zrozumienie oraz pomoc w } \\
\text { zaspokojeniu potrzeb pa- } \\
\text { cjentki, } \\
\text { - dostosowanie pomocy do po- } \\
\text { trzeb pacjentki, } \\
\text { - zaspokojenie potrzeb pa- } \\
\text { cjentki } \\
\text { - zapewnienie pacjentce kom- } \\
\text { fortu oraz bezpieczeństwa, } \\
\text { - włączenie rodziny w pomoc } \\
\text { w zaspokajaniu potrzeb pa- } \\
\text { cjentki }\end{array}$ & $\begin{aligned}- & \text { ocenianie samoopieki [10021844] } \\
- & \text { ocenianie stopnia samodzielności } \\
& {[10002723] } \\
- & \text { zarządzanie zaburzonym procesem } \\
& \text { radzenia sobie [10031846] } \\
- & \text { ocena stopnia radzenia sobie ro- } \\
& \text { dziny [10026600] } \\
- & \text { współdziałanie z rodziną } \\
& {[10035887] } \\
- & \text { zarządzanie bezpieczeństwem śro- } \\
& \text { dowiska [10042507] }\end{aligned}$ \\
\hline
\end{tabular}


dotychczasowe miejsca, wykonuje daną czynność kilkukrotnie, zdarza się także, że ma trudności w obsłudze podstawowych sprzętów domowych. W fazie umiarkowanej u osoby chorej może dochodzić do omamów i halucynacji, w związku z czym czasem zdarza się, że osoba chora jest agresywna wobec swoich najbliższych. W fazie zaawansowanej osoba chora ma znaczne deficyty narządu ruchu, najczęściej prowadzą one do stałego unieruchomienia. W tej fazie także dochodzi do nierozpoznawania swoich najbliższych, chory wymaga ciągłej asysty w wykonywaniu czynności dnia codziennego [10].

W zależności od fazy osoba chora powinna mieć także odpowiednio dobrane leki, pod ścisłym nadzorem lekarza. Ponadto opieka pielęgniarska powinna mieć charakter holistyczny. Głównym problemem osoby chorej są zaburzenia funkcji poznawczych, pielęgniarka powinna rozpoznać wszystkie deficyty oraz pomóc zarówno chorej jak i jej rodzinie do polepszenia warunków życia, jednocześnie nie wyręczając ich. Opiekunowie osoby chorej są szczególnie narażeni na pogorszenie stanu psychicznego oraz fizycznego, w obawie o nie poradzeniu sobie w opiece nad chorym z AD. Pielęgniarka musi przede wszystkim wesprzeć rodzinę i zmotywować ją do działania, do jej zadań także należy przekazanie całej posiadanej wiedzy, która ułatwi rodzinie oraz chorej w funkcjonowaniu w środowisku domowym (opisanie pomieszczeń, uniemożliwienie samodzielnego otwierania okien i drzwi osobie chorej, zabezpieczenie gniazdek). Pielęgniarka powinna także zachęcić bliskich do skorzystania z pomocy grup wsparcia. W Polsce taką grupą jest m.in. Polskie Stowarzyszenie Pomocy Osobom z Chorobą Alzheimera $[10,11]$.

\section{Wnioski}

1. Całościowa opieka nad pacjentką ze strony personelu medycznego oraz współudział rodziny pozwolił na poprawę samopoczucia 
chorej, natomiast w celu polepszenia jakości życia dnia codziennego działania pielęgniarskie powinny być kontynuowane.

2. Dzięki zastosowaniu w procesie pielęgnowania diagnoz i interwencji pielęgniarskich ICNP® pacjentka będzie miała zapewnioną specjalistyczną opiekę.

3. Aby możliwe było osiągnięcie odpowiednich warunków życia pacjenta z chorobą Alzheimera oraz jej rodziny pielęgniarka przede wszystkim powinna zadbać o zapewnienie podstawowych potrzeb oraz bezpieczeństwo pacjenta oraz bacznie obserwować jej sytuację zdrowotną w kontekście stopnia zaawansowania choroby, wesprzeć i zmotywować chorą oraz jej rodzinę do utrzymania autonomii w czynnościach z zakresu samoopieki.

4. Powyższy plan opieki pielęgniarskiej jest zależny od następujących problemów pielęgnacyjnych pacjentki: deficyt samoopieki, kłopoty z pamięcią świeżą, utrudnione poruszanie się wynikające z postępu choroby Alzheimera, ryzyko zakrztuszenia się podczas przyjmowania posiłków oraz nietrzymanie moczu oraz stolca wynikające z postępu choroby.

\section{Bibliografia/Bibliography:}

1. Prusiński A. Neurologia praktyczna. Wydawnictwo Lekarskie PZWL. Warszawa 2015:300-302.

2. Waliś R. Sposób na Alzheimera. Wydawnictwo Albatros. Warszawa 2018: 10-28.

3. Leszek J. Choroby otępienne. Teoria i praktyka. Wydawnictwo Continuo. Wrocław 2011;25-26:77-78.

4. Nieckarz R.: Opieka pielęgniarska nad pacjentem z chorobą Alzheimera. Opisy przypadku. Puls Uczelni. 2015,(9)2:19-23. 
5. Gaweł M., Potulska-Chromik A. Choroby neurodegeneracyjne: choroba Alzheimera i Parkinsona. Postępy Nauk Medycznych. 2015;7:468-476.

6. Jaracz K. Pielęgniarstwo neurologiczne. Wydawnictwo Lekarskie PZWL. Warszawa 2015:286-289.

7. Kózka M., Płaszewska-Żywko Lucyna. Diagnozy i interwencje pielęgniarskie. Wydawnictwo Lekarskie PZWL. Warszawa 2019:15-331.

8. Snarska K., Kwitek A. Problemy pielęgnacyjne chorych z chorobą Alzheimera. [w:] Cybulski M., Krajewska-Kułak E., Kowalczuk K.(red.) Pielęgnacyjno-rehabilitacyjne problemy starzejącego się społeczeństwa. Monografia. Białystok 2016:23-48.

9. Długosz-Mazur E., Bojar I., Gustaw K. Niefarmakologiczne metody postępowania u chorych z otępieniem. Medycyna Ogólna i Nauki o Zdrowiu. 2013;19(4):459-460.

10. Klimkowicz-Mrowiec A. Choroba Alzheimera. Medycyna Praktyczna.

11. https://www.mp.pl/pacjent/neurologia/choroby/151134,choroba-alzheimera (dostęp: 18.03.2020 r.).

12. Górna K., Jaracz K., Rybakowski F. Pielęgniarstwo psychiatryczne. Podręcznik dla studiów medycznych. Wydawnictwo Lekarskie PZWL. Warszawa 2012:419-430. 